\title{
Causality Test of Budget and Current Account Deficits in Nigeria: Evidence from Toda and Yamamoto Modified Wald Analysis
}

\author{
Imimole, Benedict (Ph.D) \\ Department of Economics, Faculty of Social Sciences, \\ Ambrose Ali University, Ekpoma, Nigeria
}

\begin{abstract}
This paper has investigated the direction of causality between budget deficits and current account deficits in Nigeria within a vector autoregressive (VAR) framework. The Modified Wald test procedure of Toda and Yamamoto (1995) for causality analysis was applied to Nigeria's annual data series for the period 1970-2015. This involves testing each of the series to determine the maximal order of integration (d-max), determining the optimum lag length $(\mathrm{K})$ and conducting the Modified Wald test. The results of the first two revealed the maximal order as 2 , and the optimum lag length as 5. The Modified Wald test was then conducted by estimating the VAR models in their levels with a total of $(\mathrm{K}+\mathrm{d}$-max) lags. The results revealed a bi - directional relationship between the two deficits. This means that causality between the two deficits flows from both directions - from fiscal deficits to current account deficits, and from current account deficits to fiscal deficits. To address the problem that may result from this kind of relationship, appropriate policy variables for reducing budget deficits such as taxes and government expenditure, should be manipulated in order to reduce current account deficits. In the same vein, relevant policy measures such as export promotion, equilibrium exchange rate, etc. that would reduce current account deficits should be vigorously pursued as these could play vital role in reducing fiscal deficits.
\end{abstract}

Keywords: Budget Deficit, Modified Wald Test, Causality Test, Current Account Deficit.

\section{INTRODUCTION}

Budget deficit (also called fiscal deficit) is the terminology used in describing a scenario where a nation's total spending exceeds its total revenue. Intuitively, this kind of scenario does not sound like positive development, and most conservative investors and politicians would agree that it does not. However, most economists would argue that deficit spending can be a useful tool for jumpstarting a stalled economy. McWhinney (2010) noted that when a nation is experiencing a recession, deficit spending often helps to finance infrastructure projects, which results in the purchase of materials and hiring of workers. According to him, when these workers spend their money, the economy can be boosted.

A nation is said to be running a current account deficit when it imports more goods and services than it exports, or buys from other countries and foreign companies more than it sells to them. Again, intuition suggests that running a current account deficit is not good news. It cost money, as interest must be paid to service whatever debt that is incurred.

Economies that have both budget deficit and current account deficit are often referred to as having "twin deficits" and the macroeconomic theory that associates a large budget deficit to a large current account deficit is often referred to as the "Twin deficit hypothesis". The logic behind the theory is that government tax cuts, which reduce revenue and increase the deficit, results in increased spending on the part of taxpayers, whose disposable income has increased. 
The increased spending reduces the national savings rate, causing the nation to increase the amount it borrows from abroad.

In recent years, the argument that budget deficit fuels current account deficit has returned to the forefront of policy debate. This situation was first experienced in the United States of America in the 1980s when a significant deterioration in the US current account balance accompanied a sharp increase in the federal budget deficit (Bartolini and Labiri, 2006).

For a long time, studies on the link between budget deficit and current account deficit have been centred on the validity of two major theoretical models; the Keynesian proposition and the Ricardian Equivallence hypothesis. While the Keynesian proposition holds that a cause and effect relationship exists between budget deficit and current account deficit, and that causality flows from budget deficit to current account deficit; the Ricardian Equivallence hypothesis posits that a cause and effect relationship does not exist between the two deficits (Chowdhury, 2007; Olanipekun, 2012). Outside these two age - long causal arrangements, empirical literature have further uncovered other causal patterns, that the underlying relationships between the two deficits can now be conveniently classified into the following four (4) main causal patterns:

a) Budget deficits cause external deficits

b) External deficits cause Budget deficits

c) The two deficits are not causally related, and

There is bi-directional relationship between the two deficits

\section{Objective of the Study}

The main objective of this paper is to examine the causal relationship between budget deficit as captured by Fiscal Balance (FBL), and current account deficit as expressed by Current Account Balance ( $\mathrm{CAB}$ ), with a view to identifying the causal pattern that holds for Nigeria. The period covered by the investigation is 45years, spanning from 1970 to 2015.

\section{HYPOTHESES OF THE STUDY}

The hypotheses tested in this study have been expressed in their null form as follows:

$\mathbf{H}_{\mathbf{0}}$ : Current account balance (CAB) does not Granger-cause Fiscal balance (FBL)

$\mathbf{H}_{0}$ : Fiscal balance (FBL) does not Granger-cause Current account balance (CAB)

The strength and direction of causality between fiscal deficit and current account balance has been extensively investigated in previous studies using the conventional granger causality framework (Islam, 1998; Piersanti, 2000; Gancho, 2010; Saeed and Khan, 2012; Mandishekwa, Tambudzai and Marufu, 2014). The granger causality test is a statistical hypothesis test for determining whether one variable is useful in forecasting another. This test has been blamed for concentrating on time rather than causality itself (Abdur and George, 2003). In most cases, time series data are non-stationary, which means that parameters estimated from the nonstationary variables do not follow the standard statistical distribution for testing significance and have to be differenced. Granger causality is done in an environment of Error correction (Granger, 1988). The Error correction models (ECMs) like Engel Granger Error correction model and Johansen \& Joselius Vector Error correction models help omit misrepresentation and omission of important constraints. The Error correction models are sensitive to the value of nuisance parameters in finite samples, making the results unreliable (Toda \& Yamamoto, 1995) and involve cumbersome process which results in loss of simplicity and ease of application (Rambaldi \& Doran, 1996). This study examines the causality between fiscal deficit and current account balance in Nigeria, using the most recent data for the period 1970 to 2015. 
Unlike other empirical studies carried out in Nigeria that used the traditional Granger Causality methodology, this paper has utilized the Modified Wald (MWALD) causality test as proposed by Toda and Yamamoto (1995) because of the limitations associated with the conventional granger causality test as presented above.

It would be recalled that the body of evidence in the literature for both developed and developing economies have not yielded a consensus on the causal relationship between the two deficits. Based on this existing controversy in the literature coupled with the use of the recently developed Toda and Yamamoto methodology and the scanty research in the case of Nigeria with this new methodology, this study intends to fill this gap by employing the Toda and Yamamoto (1995) Modified Wald procedure to investigate the causal relationship between fiscal deficit and current account deficits in Nigeria.

The rest of the paper proceeds as follows. Section two provides the theoretical framework of the study. Section three reviews related literature. Section four discusses the method and model specification. Empirical results are presented and discussed in section five, while section six concludes the paper.

\section{THEORETICAL FRAMEWORK}

The causality relationship between current account deficit and Fiscal deficit is premised on the argument that fiscal deficits and current account deficits are related with the former causing the latter. Theoretically, the economic reasoning that guides this connection between current account balance (CAB) and fiscal balance (FBL) derive their basis from the national income accounting identity, which is given as follows:

$$
Y=C+I+G+(X-M)
$$

Where $\mathrm{Y}=$ National Income

$\mathrm{C}=$ Private Consumption spending

$\mathrm{I}=$ Real Investment spending in the economy

$\mathrm{G}=$ Government spending on goods and services

$\mathrm{X}$ and $\mathrm{M}$ are exports and imports respectively, and the difference between them as shown in equation 1 above, is the current account deficit which is captured in our equation as CAB.

Equation 1 above may also be written as

$Y=C+S+T$

Where $\mathrm{Y}$ and $\mathrm{C}$ are as earlier defined

$\mathrm{S}=$ Private savings

$\mathrm{T}=$ Tax revenue

Substituting $\mathrm{Y}=\mathrm{C}+\mathrm{S}+\mathrm{T}$ in equation 1 , we have

$C+S+T=C+I+G+(X-M)$.

From equation 3 , we have

$(X-M)=(S-I)+(T-G)$.

Equation 4 shows that current account balance (X-M) depends on savings deficit (S-I) and fiscal balance (T-G). Economists trained in the Keynesian thinking are of the view that current 
account deficit results from fiscal deficit. This implies that current account deficit is dependent on fiscal deficit, and that any change in fiscal deficit can cause a change in current account deficit. Two possible inferences can therefore be drawn from equation 4; the first is what happens when it is assumed that (S-I) is constant or stable over time. If this is the case, then changes in the fiscal side (T-G) of equation 4 could cause fluctuation in the current account side, and either the assertion of the twin deficit hypothesis will hold (see Dudley and McKelvey, 2004; Salvatore, 2006 \& Suresh and Tiwari, 2014) or the assertion of the twin divergence hypothesis will hold (see Cavaiio, 2005; Corsetti and Muller, 2005; Kim and Roubini, 2008 \& Tosun et al., 2014). The second inference is drawn if (S-I) is not stable over time. If this happens, then changes in the fiscal side (T-G) of equation 4 could be offset by changes in (S-I) and the assertion of both twin deficit hypothesis and twin divergence hypothesis would not hold. In this case, fluctuation in the fiscal and current account deficit will be unrelated (Suresh and Tiwari, 2014). The main argument behind the twin deficit hypothesis from the Keynesian view is that excessive borrowing by government to finance its spending results in fiscal deficit that crowds out the financial resources available in the economy. The resulting fiscal deficit according to Sakyi and Opoku (2016), leads to fluctuation in the current account through (i) the increasing of domestic interest rate (as a result of the crowding out), (ii) the exchange rate, and (iii) the extent of inflow of capital.

\section{EMPIRICAL LITERATURE}

Several empirical studies have tested the causal link between current account balance and fiscal balance. The results of these studies have been mixed, producing three different strands. The first strand of literature supports uni-directional (one-way) causality that runs ether from current account to fiscal deficit or from fiscal deficits to current account. (see Saleh et al., 2005; Salvatore, 2006; Marinheiro, 2008; Sobrino, 2013 \& Forte and Magazzino, 2013). The second strand believes that these two deficits have no influence on each other (see Kiran, 2011 \& Tosun et al., 2014). In the third strand, a bi-directional causality is found between the two variables (see Mukhtar et al., 2007; Gancho, 2010; Oladipo et al., 2012; Pahlavani and Saleh, 2009; Omoniyi et al., 2012; Alam et al., 2014).

The study by Islam (1998) examined the relationship between budget deficits and trade deficits for Brazil from 1973:1 through 1991:4 using the traditional Granger Causality test, and found that there is presence of bilateral causality between trade deficits and budget deficits.

Piersanti (2000) employed the Granger-Sims causality technique to examine the relationship between the current account deficit and budget deficits for seventeen OECD countries for the period 1970 - 1997. The results revealed that there is strong evidence to support the view that current account deficits have been associated with large budget deficits during the period being investigated in most industrial countries.

Gancho (2010) investigated the relationship between the two deficits for Bulgaria using annual data series from 2000 to 2010, Granger Causality and vector error correction model. The results showed that causality flows from current account deficits to budget deficits. The study therefore concluded that twin deficit hypothesis is not valid for Bulgaria and that fiscal policy should not be used as a substitute for monetary policy.

Saeed and Khan (2012) used annual data for 1972 -2008 to investigate the dynamics of the two deficits in Pakistan using Johansen Maximum Likelihood procedure for long-run cointegration and Granger causality methodologies. The research found out that a long-run relationship 
exists between the two deficits, and that causality runs from budget deficits to current account deficits. They therefore concluded that the twin deficit hypothesis holds for Pakistan.

Alam et al., (2014) using Granger Causality test and data for the period, 1972/73 to 2011/12, found a bi-directional causality between fiscal and current account deficits for Banglandesh.

Mandishekwa Tambudzai and Marufu (2014) investigated the applicability of the two deficit hypothesis in Zimbabwe using Johansen cointegration and Granger causality tests. The findings indicate that the twin deficit hypothesis holds for Pakistan.

A review of empirical literature on Nigeria has far reaching results. For instance, Egwakhide (1997) focused on the relationship between budget deficit and current account balance in Nigeria for the period 1973-1993. He used a macroeconometric model that captured the interrelationship between government budgetary developments, credit creation and current account balance. The study found that budget deficit leads to a deterioration of the current account.

Egwakhide et al (2002) extended the work of Egwakhide (1997) by investigating the relationship between government budget deficit or surplus and current account balance using a group of African countries including Nigeria. Their main finding was that causality runs from current account balance to budget balance.

Enang (2011) adopted the Granger Causality test, the cointegration test and the variance decomposition and impulse response function to investigate the impact of macroeconomic policy, non-policy and financial sector variables on Nigeria's current account balance. The results showed that exchange rate, monetary policy credibility and budget deficits are important macroeconomic variables that influence current account movement in Nigeria.

Omoniyi et al., (2012) using Granger Causality test and data for the period, 1970 to 2008, found bi-directional causality between fiscal deficits and current account deficits valid for Nigeria.

By employing Toda and Yamamoto granger causality test, Lau and Baharumshah (2004) used annual data for 1976-2000 to analyze the relationship between the two deficits for Malaysia. The authors found support for bi-directional causality.

Lau, Mansor and Puah (2010) examined the causal link between the two deficits for four (4) countries - India, Malaysia, Thailand and Indonesia. While still making use of the Toda and yamamoto granger causality methodology, the authors found support for bi-directional causality in India and Malaysia just like the study by Lau and Baharumshah two years before. The study also found strong support for twin deficit hypothesis for Thailand, while for Indonesia, the reverse causality was confirmed.

\section{METHODOLOGY}

Granger causality by Granger (1969) is one of the earliest methods developed to estimate causal effects from time series observations. Causality testing in this sense is conventionally conducted by estimating VAR models. In this framework, a time series $\mathrm{X}_{1 \mathrm{t}}$ Granger-causes another time series $\mathrm{X}_{2 \mathrm{t}}$, if series $\mathrm{X}_{2 \mathrm{t}}$ can be predicted with better accuracy by using past values of both $\mathrm{X}_{1 \mathrm{t}}$ and $\mathrm{X}_{2 \mathrm{t}}$ rather than it can, by using the past values of $\mathrm{X}_{2 \mathrm{t}}$ alone. Hence both variables 
are endogenous and depend on their lag values. It is important to note that the above test is applicable to stationary series. However, in reality time series data are in most cases not stationary, such that the original series are usually transformed into stationary series before causality tests are conducted on them (transformed stationary series). A common nonstationary process is the I(1) process. An I(1) process may be transformed into a stationary one by taking the first order difference. If the underlying I(1) processes are cointegrated, the specification so obtained must be modified by adding the lagged value of the cointegration relation (ie the error correction term) as an additional explanatory variable (Engle and Granger, 1987). As Johansen (1988) has noted, this evidence of cointegration among the variables rules out spurious correlation, and also implies at least one direction of Grangercausality.

However, Toda and Phillip (1993) have provided evidence that the Granger-causality tests in ECM still contain the possibility of incorrect inference. According to them, such inference suffers from nuisance parameter dependency, asymptotically (see Shirazi and Manap, 2004). It is for this and other reasons earlier expressed that Toda and Yamamoto (1995) proposed a procedure that allows for causal inferences to be made at level VARs that may not be stationary without the use of rigorous pretests and strict reliance on cointegration and integration properties. They proposed a modified Wald - MWald - for testing Granger non-causality which imposes non-linear restrictions on the properties of the VAR models. This implies that there may be no need to test for unit root and cointegration ranks. The procedure is not only simple, it has also been found to be superior to both the LR test (Moscani \& Gianni, 1992) and the Wald test of Toda \& Phillips (1993, 1994), as verified by Zapata \& Rambaldi (1997).

Following Veulemans (2012), the bivariate VAR (k) model of the Toda-Yamamoto based Granger-causality model may be specified as follows.

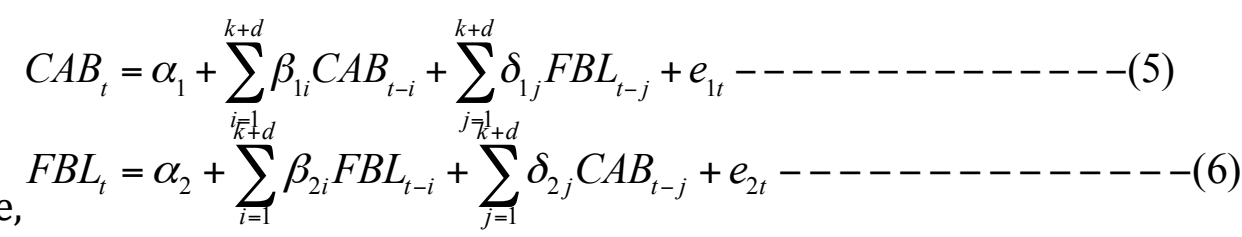

$\mathrm{d}=$ Maximal order of integration of the variables

$\mathrm{K}=$ Optimal lag length of CAB and FBL

$\mathrm{e}_{1 \mathrm{t}}$ and $\mathrm{e}_{2 \mathrm{t}}$ are the error terms which are assumed to be white noise with zero mean, constant variance and no autocorrelation.

We can obtain two tests from this analysis. For the first equation, the null hypothesis is $\mathbf{H}_{\mathbf{0}}$ : $\mathrm{CAB}_{\mathrm{t}}$ does not Granger-cause $\mathrm{FBL}_{\mathrm{t}}$ if $\sum_{j=1}^{k} \delta_{1 j}=0$ against the alternative hypothesis $\mathbf{H}_{\mathbf{1}}$ : CAB $\mathrm{t}$ does Granger-cause FBLt if $\sum_{j=1}^{k} \delta_{1 j} \neq 0$

For the second equation, the null hypothesis is

$\mathbf{H}_{\mathbf{0}}$ : FBLt does not Granger-cause $\mathrm{CAB}_{\mathrm{t}}$ if $\sum_{j=1}^{k} \delta_{2 j}=0$ against the alternative hypothesis

$\mathbf{H}_{\mathbf{1}}$ : FBLt does Granger-cause $\mathrm{CAB}_{\mathrm{t}}$ if $\sum_{j=1}^{k} \delta_{2 j} \neq 0$ 
If we accept the first null hypothesis and reject the second, then we conclude that changes in FBLt are Granger-caused by a change in $\mathrm{CAB}_{\mathrm{t}}$. Unidirectional causality will occur between the two variables if either the null hypothesis of equation 5 or 6 is rejected. Bi-directional causality will occur if both null hypotheses are rejected. Absence of causality (no causality) will occur if neither the null hypothesis of equation 5 nor 6 is rejected.

Four stages are involved in the implementation of the Toda-Yamamoto Modified Wald procedure. The first is to test each of the series to determine the maximum order of integration ( $\mathrm{d}$ max of the variables in the system). This involves using such tests as Augmented DickeyFuller (ADF) test, Phillips-Perron (PP) test or Kwiatkowski, Phillips, Schmidt and Shin (KPSS) test. The second stage is to determine the optimal lag length $(\mathrm{k})$. The lag length $(\mathrm{k})$ is always unknown and has to be obtained in the process of the VAR in levels among the variables in the system by using different lag length criterion such as the AIC, SC, FPE, HQ information criterion. The third stage is to estimate the $(\mathrm{k}+\mathrm{d} \text { max })^{\text {th }}$ order level VAR model and the coefficients (Rambaldi and Doran, 1996 \& Zapata and Rambaldi, 1997). The final stage is to use the Modified Wald procedure to test the VAR $(\mathrm{k})$ model for causality and then make a Granger causal inference for the variables in the VAR system.

The study has made use of secondary data obtained from the Central Bank of Nigeria (CBN) statistical Bulletin (various issues). The variables used in the study are Budget and Current Account balance expressed in billion Naira. The Modified Wald (MWALD) procedure developed by Toda and Yamamoto (1995) was employed to investigate the causal relationship between budget and current account balance in Nigeria.

\section{EMPIRICAL RESULTS}

This study has investigated the nature and direction of causality between current account balance (CAB) and fiscal balance (FBL) in Nigeria using annual data for the period $1970-2015$. In doing this, the modified version of Granger causality test of Toda and Yamamoto (1995), which requires information about the optimal lag length $(\mathrm{k})$ and maximal order of integration (d max) of the two variables was used.

Before conducting the causality test, it was necessary to first of all determine the maximum order of integration for the system using the Phillip Peron unit root test, and to test for the optimal lag length. The maximum order of integration ( $d$ max) was obtained as two (2) from Phillips Peron (PP) unit root test since revelation from the test indicates that current account balance $C A B$ was stationary at $2^{\text {nd }}$ difference, while fiscal balance FBL was stationary at $1^{\text {st }}$ difference. The results of the unit root test are presented in Table1 below.

Table1: Phillip Peron Unit root Test

\begin{tabular}{|l|l|l|l|}
\hline Variable & PP Test Statistic & Critical Values (5\%) & Order of Integration \\
\hline CAB & -7.9251 & -2.9314 & $\mathrm{I}(2)$ \\
\hline FBL & -6.2935 & -2.9297 & $\mathrm{I}(1)$ \\
\hline
\end{tabular}

The optimal lag length of the system was also investigated. The results revealed that an optimal lag of five (5) was chosen as selected by the information criteria - LR, FPE, AIC and HQ. This is reported in Table 2 below. 
Table2: Lag Length Selection

\begin{tabular}{|l|l|l|l|l|l|}
\hline Lag & LR & FPE & AIC & SC & HQ \\
\hline 0 & NA & $3.98 \mathrm{e}+11$ & 32.38652 & 32.47011 & 32.41696 \\
1 & 105.3993 & $3.02 \mathrm{e}+10$ & 29.80798 & 30.05874 & 29.89929 \\
2 & 19.98465 & $2.11 \mathrm{e}+10$ & 29.44797 & 29.86591 & 29.60016 \\
3 & 8.613843 & $2.00 \mathrm{e}+10$ & 29.38974 & 29.97487 & 29.60281 \\
4 & 35.70294 & $8.04 \mathrm{e}+09$ & 28.46915 & $29.22145^{*}$ & 28.74309 \\
5 & $10.16211^{*}$ & $7.05 \mathrm{e}+09^{*}$ & $28.32553^{*}$ & 29.24501 & $28.66036^{*}$ \\
\hline
\end{tabular}

The empirical results of the Granger causality test based on the Toda Yamamoto methodology are reported in Table3 below.

Table3: Toda - Yamamoto Causality (MWald) Test Results

\begin{tabular}{|l|l|l|l|l|}
\hline Null Hypothesis & df & Chi-sq & Prob & Direction of causality \\
\hline FBL does not granger cause CAB & 5 & 26.23854 & 0.0001 & FBL to CAB \\
\hline CAB does not granger cause FBL & 5 & 30.86514 & 0.0000 & CAB to FBL \\
\hline
\end{tabular}

The test result followed the chi-square distribution with 5 degrees of freedom in accordance with the appropriate lag length along with their associated probability. The results showed that we can reject the null hypothesis that FBL do not granger cause CAB at $5 \%$ level of significance. Also, we can reject the null hypothesis that CAB does not granger-cause FBL at 5\% level of significance in Nigeria. This result indicates a bi-directional causality between Fiscal deficit and current account balance in Nigeria. In other words, causality flows from FBL to CAB and back again from $\mathrm{CAB}$ to FBL during the sample period. The paper affirms that twin deficits hypothesis as well as the reverse situation is present in Nigeria.

\section{CONCLUDING REMARK}

In this paper, we have examined the relationship between Fiscal deficits and current account balance in Nigeria for the sample period 1970 - 2015, using the Modified Wald procedure of Toda and Yamamoto (1995). The results revealed a bi-directional causality relationship between fiscal deficits and current account balance during the sample period. This means that causality between the two deficits flows from both directions - from fiscal deficits to current account deficits, and from current account deficits to fiscal deficits. This result agrees with the one earlier obtained by Omoniyi et al., (2012) while using the traditional Granger Causality methodology.

Given the findings of this paper, it is recommended that appropriate policy variables for reducing budget deficits such as taxes and government expenditure, should be manipulated through expenditure cut and tax increase, in order to reduce current account deficits. In the same vein, relevant policy measures such as export promotion, equilibrium exchange rate, etc. that would reduce current account deficits should be vigorously pursued as these could play vital role in reducing fiscal deficits.

\section{References}

Abdur, C. and George, M. (2003). FDI and Growth: What causes what? A Paper presented at the WIDER Conference on "Sharing Global Prosperity" WIDER, Hesinki, 6-7, September.

Alam, K.J., Ghosh, B.C., Islam, S. and Hossain, E. (2014). Empirical Analysis of Twin Deficits in Bangladesh, Journal of Humanities and Social Science, 19(1), 65-72.

Bartolini, L. and Labiri, A. (2006). Twin Deficits, twenty years later. Current Issues in Economics and Finance, 12 (7), hlm. 1-7, October.

Cavallo, M. (2005b). Understanding the Twin Deficits: New approaches, new results. FRBSF Economic Letter, hlm. $1-4$, July. 
Chowdhury, K. and Saleh, A.S. (2007). Testing the Keynesian Proposition of Twin Deficits in the Presence of Trade Liberalisation: Evidence from Sri Lanka. University of Wollongong. Economic Working Paper Series. WP 07-09, 1-3. Corsetti, G. and Muller, G. (2006). Twin Deficits: Squaring Theory, evidence and Common sense. Economic Policy. 48, 597-638.

Dudley, W.C. and McKelvey, E.F. (2004). The US Budget Outlook: Surplus of Deficits. Global Economic Papers 106, Goldman Sachs, New York.

Egwaikhide, F.O. (1997) Effects of Budget Deficit on Current Account Balance in Nigeria: A Simulation Exercise AERC Research Paper, No 70.

Egwaikhide, F.O., Ayodele, S.O., Oyeranti, O.A. and Tchokote, J. (2002) Causality Between Budget deficit and the Current Account Balance in African Countries. West African Journal of Monetary and Economic Integration, 2(2), 10-41.

Enang, B. (2011). Adjustment Policies and Current Account Behaviour: Empirical Evidence from Nigeria. European Journal of Humanities and Social Sciences, 6(1), 1-16.

Engle, R. and Granger, C. (1987). Cointegration and Error Correction: Representation, Estimation and Testing. Econometrica, 55, 251-271.

Forte, F. and Magazzino, C. (2013) "Twin Deficits in European Countries. International Advances in Economic Research, 19, 289-310.

Gancho, T.G. (2010). The Twin Deficit Hypothesis: The case of Bulgaria. Financial Theory and Practice, 34(4), 357377.

Granger, C.W.J. (1969). Investigating Causal relationships by Economic Models and Cross Spectral models. Econometrica, 37, 424-438.

Granger, C.W.J. (1988). Some Recent Developments in Concept of Causality. J. Econs, 39, 199-211.

Johansen, S. (1988). Statistical Analysis of Cointegration Vectors. Journal of Economic Dynamics and Control, 12(2), 231-254.

Kim, S. and Roubini, N. (2008). Twin Deficit or Twin Divergence? Fiscal Policy, Current Account and Real Exchange Rate in the US. Journal of International Economics, 74, 302-383.

Kiran, B. (2011). On the Twin Deficits Hypothesis: Evidence from Turkey, Applied Econometrics and International Development, 11(1), 56-66.

Lau, E. and Baharumshah, A.Z. (2004). On the Twin Deficit Hypothesis: Is Malaysia different?, Pertanika Journal of Social Sciences and Humanities, 12(2), 87-100.

Lau, E. Mansor, S.A. and Puah, C.H. (2010). Revival of the Twin Deficits in Asian crisis-affected countries, Economic Issues, 15(1), 29-53.

Marinheiro, C.F. (2008). Ricardian Equivalence, Twin Deficits and Feldstein-Horioka Puzzle in Egypt, Journal of Policy Modeling, 30(6),1041-1056.

Mandishekwa, R., Tambudzai, Z. and Marufu, A. (2014). Testing the Applicability of the Twin Deficits Hypothesis in Zimbabwe; Journal of Economics and Sustainable Development, 5(28).

McWhinney, J.E. (2010). Twin Deficits: Twice the Fun for the US

Oladipo, S.O., Oseni, I.O. and Onakoya, A.B. (2012). Empirical Analysis of Twin Deficits in Nigeria. International Journal of Management and Business studies, 2(3) July-September.

Olanipekun, D.B.(2012). A Bound Testing Analysis of Budget Deficits and Current Account Balance in Nigeria 1960-2008. International business Management, 6(4), 408-416.

Omoniyi, O.S., Olasunkanmi, O.I. and Babatunde, O.A. (2012). Empirical Analysis of Twin Deficits in Nigeria, International Journal of Management and Business Studies, 2(3), 38-41.

Islam, M.F. (1998). Brazil’s Twin Deficits: An Empirical Examination. Atlantic Economic Journal, 26(2), $121-271$.

Pahlavani, M. and Saleh, A.S. (2009). Budget Deficits and Current Account Deficits in the Philippines. A Causal Relationship, American Journal of Applied Sciences, 6(8), 1513-1520. 
Piersanti, G. (2000). Current Account Dynamics and Expected Future Budget Deficits: Some International Evidence. J. Int. Money Finance, 19, 255-271.

Rambaldi, A. and Doran, H. (1996). Testing for Granger Non-Causality in Cointegrated Systems Made Easy. Working Papers in Econometrics and Applied Statistics, Department of Econometrics, University of New England, No. 88.

Saeed, S. and Khan, A. (2012). Twin Deficit Hypothesis: The case of Pakistan 1972-2008. Natural and Applied Sciences, 3(2), 133-162.

Sakyi, D. (2011). Trade Openness, Foreign Aid and Economic Growth in Post-liberalisation Ghana. An Application of the ARDL Bounds Test. Journal of International Economics and Finance, 3(3), 146-156.

Salvatore, D. (2006). Twin Deficits in G-7 Countries and Global Structural Imbalances. Journal of Policy Modeling, $28,701-712$.

Sobrino, C.R. (2013). The Twin Deficits Hypothesis and Reverse Causality: A shortrun Analysis of Peru, Journal of Economics, Finance and Administrative Science, 18(34), 9-15.

Suresh, K.G. and Tiwari, A.K. (2014). A Structural VAR (SVAR) Analysis of Fiscal Shocks on Current Account in India, Macroeconomics and Finance in Emerging Market Economies, 7(1), 140-153.

Toda, H.Y. and Phillips, P.C.B. (1993). Vector Autoregression and Causality. Econometrica, 61, 1367-1393.

Toda, H.Y. and Yamamoto, T. (1995). Statistical Inferences in Vector Autoregressions with possibly Integrated Process. Journal of Econometrics, 66, 225-250.

Tosun, M.U., Iyidogan, P.V. and Telatar, E. (2014). Twin Deficits in Selected Central and Eastern European Economies: Bounds Testing Approach with Causality Analysis. Romanian Journal of Economic Forecasting, 17(2), 141-160.

Zapata, H.O. and Rambaldi, A.N. (1997). Monte Carlo Evidence on Cointegration and Causation. Oxford Bulletin of Economics and Statistics, 59(2), 285-298. 